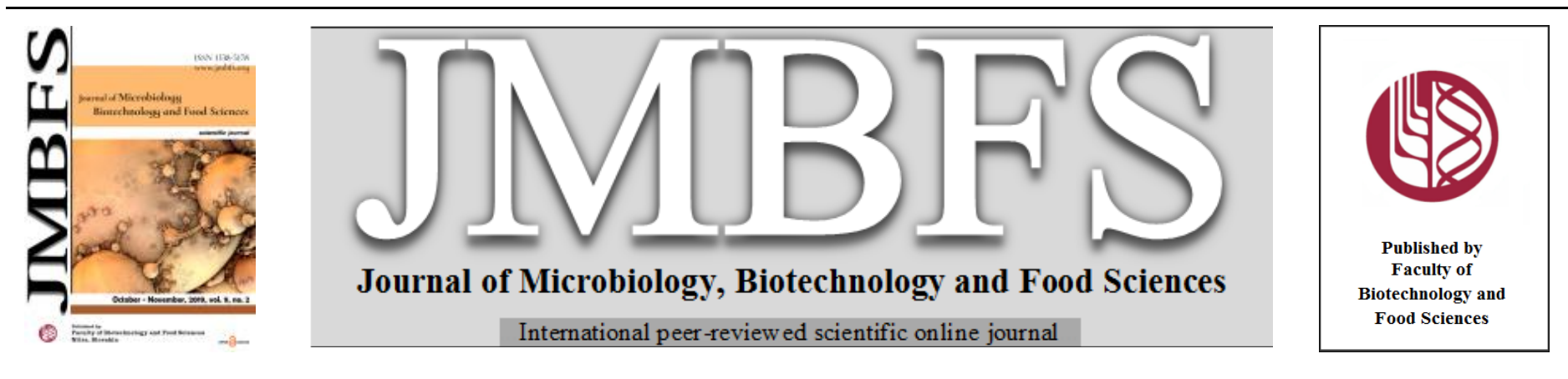

\title{
MICROENCAPSULATION: AN OVERVIEW FOR THE SURVIVAL OF PROBIOTIC BACTERIA
}

\author{
Khyati Oberoi ${ }^{l}$, Aysu Tolun ${ }^{2}$,Kanika Sharma ${ }^{3}$ and Somesh Sharma ${ }^{* 4}$ \\ Address(es): \\ ${ }^{1}$ Faculty of Applied Sciences and Biotechnology, Shoolini University, Solan, Himachal Pradesh, India, 173229. \\ ${ }^{2}$ Ankara University, Faculty of Engineering, 06110 Ankara, Turkey. \\ ${ }^{3}$ Faculty of Applied Sciences and Biotechnology, Shoolini University, Solan Himachal Pradesh, India, 173229.
}

*Corresponding author: someshsharma@ shooliniuniversity.com

doi: 10.15414/jmbfs.2019.9.2.280-287

\section{ARTICLE INFO}

Received 11. 10. 2018

Revised 4. 4. 2019

Accepted 17. 4. 2019

Published 1. 10. 2019

Review

OPEN $\bigodot_{\text {AcCESS }}$

\begin{abstract}
For maintaining good health, one needs a proper balance and composition of intestinal microflora which can be achieved by supplementing probiotics. A noteworthy issue in creating helpful and valuable probiotic food items is bacterial survival, amid capacity and ingestion. Several gastrointestinal diseases can be reduced by colonizing Probiotic supplement as the appropriate barrier in the small intestine. Probiotic is characterized as a suitable microorganism with several medical advantages to the consumer when administrated in a satisfactory amount. The poor survival and steadiness of the probiotic microorganisms as revealed from the earlier reports is an essential question to that impact. Diverse natural components like oxygen toxicity, an intolerant condition of acidity and travel through the gastrointestinal tract offers a variety of extreme conditions to the probiotic microorganisms. Therefore, the current review is more emphasized upon the microencapsulation of the probiotics that enhance their viability against different parameters like oxidation, light, moisture, and temperature. Recent advancements in ensuring microorganism survival rate and their colonization in the gut as gut microflora using microencapsulation enhance probiotic supplements for better health. Hence, the present review also emphasis on the methodological systems used for probiotic alive by the encapsulation process advance technologies used to stabilize their viability during storage including the selection of biomaterial and decision for proper innovation.
\end{abstract}

Keywords: microencapsulation, probiotic, health benefits, gastrointestinal, polymeric matrix, survival

\section{INTRODUCTION}

Probiotics are generally microbial supplements of beneficial microorganisms which surpasses the gastrointestinal tract and provide the medical advantages to the host when managed in the satisfactory amount by enhancing the properties of microflora (Ammor et al., 2007). The remarkable choice of the microorganism to be considered as probiotic depends on the fluke that it is a typical inhabitant of the gastrointestinal tract, stay active along the route through the gastrointestinal tract and draw out its suitability and reliability in the digestive system (Cook $\boldsymbol{e t}$ al., 2012). Important probiotics give various medical advantages identified with the counteractive action of harmful microscopic organisms by the aggressive prohibition against gastrointestinal pathogens and through the preservation of typical intestinal microflora. Besides, these probiotics built the resistant framework, cover the treatment of lactose bigotry and create vitamin B (Rasic, 2003). The investigations of the prominent countless microorganisms comprise of various strains of lactobacillus and Bifidobacteria(Theodorakopoulouet al., 2013). Bacterial culture used as a probiotic enhances the development of the favored microbes, removes unwanted microbes and builds up the normal functions of the body. The general soundness of the individual relies upon an individual way of life or dietary patterns. In various food products, probiotic microbes have been enhanced as an approach to expand their good quality and probiotic characteristics (Sullivian, 2005). In the present era, these are of great importance in many food industries to develop new products with probiotic characteristics (Doherty et al.,2012). Further, the application of microencapsulation techniques upgrades the security of the probiotic product(Tolun et al., 2016).

\section{UTILIZATION OF MICROENCAPSULATION FOR THE SURVIVAL OF PROBIOTIC BACTERIA}

Microencapsulation of microorganism is one of the most recent and effective techniques to secure microbes against serious ecological elements and coat them with proper biomaterial for suitable release in the intestinal medium (Mortazavianet al., 2008). Microencapsulation help in segregating Probiotic bacteria from the harsh environment of the gastrointestinal tract Microencapsulation of probiotic bacteria as exemplified in Fig 1, shows the core material based on proteins as a useful nourishment for the probiotic cells which is a promising alternative to polysaccharide hydrogels. These biomaterials frame a boundary to secure the center material against the gastrointestinal condition (Zuidam and Shimoni, 2007).

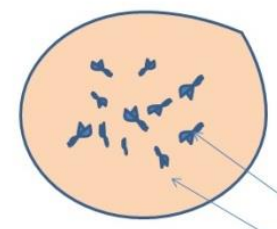

core material

shell material

Multinuclear microcapsule Continuous mononuclear microcapsule

Figure 1 Schematic demonstration of a Microcapsule.

\section{MICROCAPSULE AND A MICROBEAD}

Altered polymers of sugars, gums, proteins, and lipids are diverse bioactive components that are utilized to shape microcapsule and can be distinguished as reservoir type, matrix type and coated matrix type as outlined in Figure 2. The shape and smoothness of the sporadic microcapsules enhances their productivity (Mortazavian et al., 2007). Each microbead (likewise called the capsule) comprises of hydrocolloids that are secured around the cell. The gel-like structure of the core called gel-globule. In terms of the size of the particle and type of capsule, microbead comprises different characteristics. The microbead covered with the layer of the chemical compound expands the effectiveness of 

"core" (Sultana et al., 2000 and Truelstrup-Hansen et al., 2002).

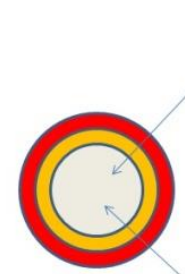

(A)

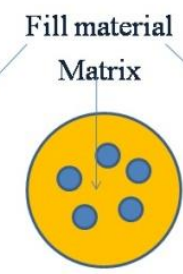

(B)

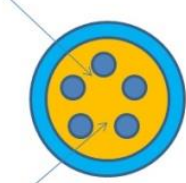

(C)
Shell microencapsulation. The constituent capture encompassed by the coat called

Microencapsulation of ascorbic acid using starch granules has been proved in maintaining high amid capacity ascorbic acid(Gupta $e t$ al., 2015).

\section{Cellulose Acetate Phthalate (CAP)}

Due to its safe nature and physically inert characteristics to the gastrointestinal tract, Cellulose Acetate Phthalate (CAP) is employed for encapsulation of probiotic bacteria. Generally, this compound is insoluble at acidic hydrogen ion concentration via due to its ionizable phthalate groups (Mortazavian et al., 2007). The addition of spray-dried Bifidobacterium animalis encapsulated in CAP together with inulin considerably increased probiotic

viability throughout storage at $5^{\circ} \mathrm{C}$ for 30days (Antunes et al., 2013).

\section{METHODS FOR PREPARATION OF MICROCAPSULES}

\section{Physical Methods}

Figure 2Structure of Microcapsule (A) reservoir type (B) matrix type (C) coated matrix type

\section{ADVANTAGES OF MICROENCAPSULATED PROBIOTICS}

The microencapsulation of the probiotics improves the survival and safety of microbes in food. The $40 \%$ of probiotic strains survive in dairy products when incorporated in a calcium alginate sphere than free cells (Sheu and Mrashall, 1993). Encapsulation is a quick, adaptable method as it permits delivery of good quality particles under $40 \mu \mathrm{m}$ with steady activity for the number of industria applications(Fang and Bhandari, 2010; Zuidam and Heinrich, 2009). Further, the system is utilized to diminish the instability and exhibit the improvement of survival in the gastrointestinal tract. Microencapsulation has been utilized to diminish the conceivable threat of harmful substances such as fumigants, herbicides and pesticides.

\section{BIOMATERIALS UTILIZED FOR THE MICROENCAPSULATION OF PROBIOTICS}

\begin{abstract}
Alginate
Alginate and its mix are regularly utilized as an exemplifying material because of its non-harmful nature and being promptly accessible. Alginate is removed and filtered from various sorts of green growth. It is a straight heteropolysaccharide comprising of two basic units D-mannuronic acid and L-guluronic acid. As alginate can retain water and simple to control because of the capacity to ingest and control, it is utilized as a typifying material. Due to its diverse properties such as gelling, balancing out and thickening it is utilized in various applications among the food and pharma industries (Goh and Chang et al., 2012). Further, because of its non-harmful nature and minimal effort, alginate is utilized for embodying material for probiotic microorganisms that upgrade the feasibility of microscopic organisms when presented to different ecological conditions (Burgin et al., 2011).
\end{abstract}

\section{Chitosan Polymer}

Chitosan has basically deacetylated polymer of $\mathrm{N}$-acetyl-glucosamine which comprises mainly chitin, a material found in algae and molluscs with effective biocompatibility and biodegradability. In addition, it enhances the antibacterial efficacy of the probiotic microorganisms. The property of chitosan takes care of the survival of microbes enhancing the ability and, furthermore resist in the gastrointestinal tract (Capela, 2006 and Chavarri et al., 2010). Hence, it is the most ideal approach to transport the sensible cells of the colon (Zhou et al., 1988).

\section{Xanthan gum}

It is a heteropolysaccharide that comprises of rehashed structures of the pentasaccharide units framed by two glucose units, two mannose units, and one glucuronic corrosive unit. It is synthesized by the aging of microbeXanthomonascampsetris. Xanthan is considered as essentially gelling gum and has been utilized for the embodiment of probiotic microorganisms and gives high resistance towards acidic conditions in the stomach (Sultana et al., 2000 and Chen, 2007).

\section{Starch Polysaccharide}

Starch, a polysaccharide manufactured by every green plant comprising of $\alpha$-dglucose units connected by glycosidic bonds. The probiotic cells can be embodied to the starch granules by the grip in the granules. The surface of starch granule and safe starch for the probiotic cells can achieve the condition of gastro intestine and colon when embodied. One of the important properties of safe starch is the better release of the bacterial cells in the intestinal tract (Haralampu, 2000). However, altered starch has greater coating properties.

\section{Air Suspension Covering Method}

In this technique, the central material is strongly dispersed into supporting air stream as the suspended particles are covered with unstable polymer discharge leaving a thin layer of it on the center. The procedure is repeated until the required parameters are achieved, such as covering thickness is accomplished The rate of drying is specifically relative to the temperature of an air stream as the air stream dries the particles in the suspension. The covering chamber is arranged as such that the particles move upwards through covering zones and disperse into moving air and revert back to the chamber base making the point of desirable thickness when the process is accomplished (Jackson et al., 1991). Along thickness, the different process factors to be considered such as the concentration of covering material, solubility, melting point, surface zone, density, volatility of central material, the temperature of the air stream and the measure of the fluidizing air stream.

\section{Coacervation Process}

In this process, the active central material is spread in such an arrangement of covering material that the core material doesn't break in the dissolvable medium. Coacervation occurs when there is a difference in $\mathrm{pH}$ of the medium, which is done either by including sulfuric acid, hydrochloric acid and natural acids. However, later it diminishes the solvency of shell material and continues the shape support from the microcapsule. The shell material structures a consistent covering around the center and shell to solidify. As a result here is the formation of simple and complex shapes of microcapsule coacervate (Kruif et al., 2004). The solidifying agents like formaldehyde might also be added to the procedure 1995).

\section{Pan Coating}

One of the most established strategies utilized in the pharmaceutical industries for microencapsulation. In this technique, the particles are tumbled in a pan or a device while the covering material is applied in the spray form. Further, the particles are mixed with the coating material and increased temperature results in the melting of coating material which can be gradually applied to core particles. From the start of encapsulation, core particles were wholly mixed in tumbling vessel rather than being mixed with the core particles. The arrangement associated with the particle size $>600 \mu \mathrm{m}$ usually fit for pan coating microcapsules (Kasturagi et al., 1995).

\section{Divergent Expulsion Process}

The divergent expulsion process is reasonable for fluid and slurries. In this process, the encapsulation occurs by utilizing divergent expulsion which contains concentric microbeads. The stream of central fluid encompasses by the sheath of microbead arrangements. As the stream travels through the air zones it breaks into microbeads of center each covered with wall arrangement. As the beads are in fluidized liquid, the divider is solidified and may vanish from wall arrangement. Since the beads are inside $\pm 10 \%$ mean distance across the center, they settle as a limited ring around the microbead. In this way, a container can be solidified after development by holding them in a ring formed called solidifying microbead. This procedure is capable of varied size particles of $400-2000 \mu \mathrm{m}$ and with diverse coating or polymers materials (Venkatesan et al., 2009).

\section{Spray drying and hardening strategy}

This technique is reasonable for labile medications due to minimum contact time in the spray dryer and is efficient. In spray drying, the active material is broken and suspended in polymer arrangement which is caught as the dried molecule. Both the strategies of spraying and hardening are comparable in the procedure of dispersion of the center and covering the molecule. However, there is a difference in the rate of hardening of covering. In spray drying, there is a fast dissolution of after which the suspension was dried in the fluidized bed dryer (Nihant $\boldsymbol{e t}$ al., 
dissolvable, as a result of breaking of covering material. However, during spray hardening by hot solidifying a non-dissolvable covering material is obtained Expulsion of non-dissolvable is by absorption, extraction and vanishing (Aparna, 2010).

\section{Dissolvable vanishing strategy}

This technique is broadly utilized for water-soluble and water-insoluble compounds to deliver strong fluid center microbeads. In this technique, the covering material (polymer) is broken up in an unstable dissolvable form which is immiscible with the fluid medium phase. In other words, a central material or microencapsulated form is broken down in the covering polymer arrangement With unsettling, the center covering materials blend or spread in the fluid medium phase to get the proper microcapsule size. The dissolvable vanishing strategy is accomplished by constant disturbance and by using external heat supply (Jain, 2002).

\section{METHODS FOR MICROENCAPSULATION OF PROBIOTIC MICROSCOPIC ORGANISMS}

Probiotic microscopic organisms are formed by various procedures like extrusion, emulsion and spray drying strategies. In these strategies, by utilizing the different systems probiotic microbes are trapped in the gel lattice (Champagene and Fustier, 2007). The conditions for actualizing innovation are intended to keep up cell suitability of the probiotic microorganism. In any case, the solvents occupied with the exemplification innovation ought to be non-letha (Gbassi and Vandamme, 2012). These procedures are isolated into two segments:

(A) Encapsulation Process

(B) Drying Process

\section{Encapsulation Process}

The strategies utilized for the encapsulation procedure are extrusion or bead technique and emulsion or two-stage framework strategy (King, 1995) and the carrier material is obtained by several methods such as spray chilling, spray drying, cocyrystallization, lyophilization, coacervation and thermal gelation (Poshadri and Kuna, 2010).

\section{Extrusion Technique}

Extrusion is the most common physical strategy for delivering hydrocolloid capsules (King, 1995). However, it is a poor and simple process with direct and straightforward tasks, which make the cell harm minimum and causes a relatively high suitability of probiotic microorganism. Some different particulars of this strategy are biocompatibility and adaptability (Klein and Vorlop, 1985; Martinsen et al., 1989). All things considered, the vital disadvantage of this technique is that it can't be utilized for real generation on account of its relaxed improvement of microbeads. In another way, it is difficult to scale up. The arrangement of beads size of breadth $2-5 \mathrm{~mm}$ is maximum, delivered in the emulsion technique. Probiotic encapsulated bacteria showed enhanced survival rate by ionic gelation to the microbeads with electrostatic extrusion under simulated gastric conditions in the gastrointestinal tract (Kim et al., 2016).

\section{Emulsion Technique}

Emulsion technique is viably utilized for the microencapsulation of lactic microbes (Audet et al., 1988). Similar to the extrusion system, it tends to scale up the process and the measurement of shaped globules is particularly little $(25 \mu \mathrm{m}-2 \mathrm{~mm})$. All the same, this includes extra expense for execution contras among the extrusion procedure along with the utilization of vegetable oil for emulsion arrangement (Krasaekoopt et al., 2003). In this strategy, the expansive amount of vegetable oil (as a ceaseless stage) for example soy, sunflower, cornmillet or light paraffin oil is added to the least volume of a cell (Gismondo et al. 1999).In the emulsion technique, the arrangement turns out to be fine, reliable and blending by actual increase with easy scale-up and high survival of bacteria, focusing on the estimation of microencapsulation. The best decision of Tween 80 at the grouping of $0.2 \%$ has been recommended for the arrangement of the capsule (Sheu and Marshalla, 1993). The strategy for the planning of microcapsule by emulsion appears in Fig 3. Microparticles of encapsulated probiotic bacteria produced by the emulsification process using sodium alginate as biomaterial are effective in protection under simulated gastric condition (Holkem et al., 2017).

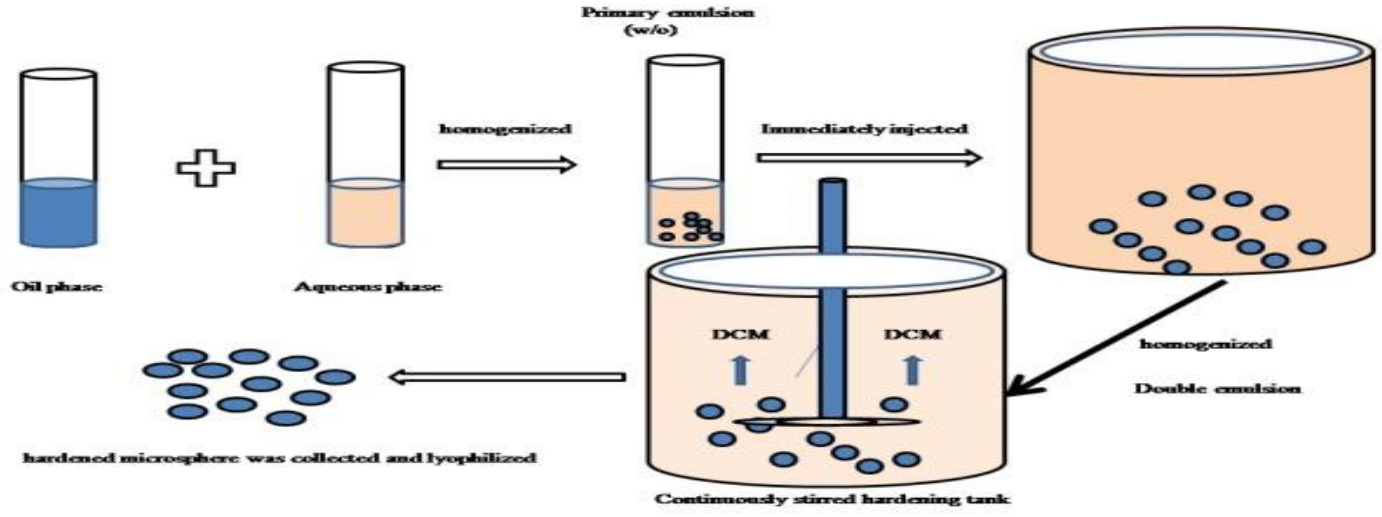

Figure 3 Method for preparation of microcapsule by emulsion technique.

\section{Drying Process}

The system of spray drying or fluidized bed drying has been broadly utilized for the drying of embodied microbes. The cells exemplified by these strategies have accomplished discharge into the item. In spite of the fact that the cells are not anchored towards the food environment and remain within the sight of gastric liquid or bile after drying process (Lankaputhra and Shah, 1995). Probiotics in solidifying dried form shape demonstrate similarity with different starter cultures, for example, cheddar cheese; however, results in realistic usability with their cell slurry formation. With specific reference to spray drying, ongoing production makes it viable in ensuring microencapsulated probiotics (Kitamura et al., 2009). This technique is normally utilized in the food industry requires atomization of fluids or efficient suspension of probiotics and transporter material into a drying gas, that outcomes in a quick dissolution of water. Water dissolution is resolved as the contrast between the air delta temperature and air outlet temperature. The spray drying process is managed by these temperatures in addition by the gas stream (Rokka and Rantamaki, 2010). The spray drying strategy requires high temperatures to encourage water dissipation that decreases the probiotic viability and their progress in the food product. As per the earlier results, it was found that the base air delta temperature ought to be $100^{\circ} \mathrm{C}$, while the most extreme $170^{\circ} \mathrm{C}$ for the probiotic exemplification life form. The air outlet temperature changes somewhere in the range of $45^{\circ} \mathrm{C}$ and $105^{\circ} \mathrm{C}$. At these temperatures, the cells hold all their probiotic action. The action of probiotic must be separated from probiotic survival. The drying process doesn't decrease cell survival and doesn't repress the stability of probiotic cells within the gastrointestinal and intestinal mucosa conditions (Piano et al., 2008). The impact of various drying strategies alongside their methods on the molecule measure has been presented in Table 1 . 
Table 1 Different drying technique along with major steps and particle size used for the encapsulation

\begin{tabular}{|c|c|c|c|c|c|}
\hline $\begin{array}{l}\text { Drying } \\
\text { Method }\end{array}$ & Mechanism & Major steps & $\begin{array}{l}\text { Particle } \\
\text { size }(\mu \mathrm{m})\end{array}$ & Cost & Example \\
\hline Spray drying & Dehydration & $\begin{array}{l}\text { Preparation of dispersion, } \\
\text { homogenization, } \\
\text { atomization of feed } \\
\text { dispersion, dehydration of } \\
\text { atomized particle. }\end{array}$ & $3-100$ & Low & $\begin{array}{l}\text { Dry flavorings, vitamin, mineral, } \\
\text { Colorant, fat oil flavor, aroma } \\
\text { compounds, enzyme etc. }\end{array}$ \\
\hline $\begin{array}{l}\text { Spray freeze } \\
\text { Drying }\end{array}$ & $\begin{array}{l}\text { Lyophilization } \\
\text { and } \\
\text { dehydration }\end{array}$ & $\begin{array}{l}\text { Atomization of dispersion } \\
\text { and low temperature } \\
\text { drying }\end{array}$ & $400-1400$ & High & Mainly probiotic bacteria. \\
\hline Lyophilization & Sublimation drying & $\begin{array}{l}\text { Mixing of core in coating } \\
\text { solution and freeze-drying } \\
\text { of the mixture. }\end{array}$ & - & High & $\begin{array}{l}\text { All heat sensitive materials and } \\
\text { aromas, water-soluble essences. }\end{array}$ \\
\hline $\begin{array}{l}\text { Fluidized bed } \\
\text { Coating }\end{array}$ & $\begin{array}{l}\text { Coating of } \\
\text { the solution }\end{array}$ & $\begin{array}{l}\text { Preparation of coating } \\
\text { solution, fluidization of } \\
\text { core particle and coating } \\
\text { of core material, } \\
\text { dehydration and cooling. }\end{array}$ & $5-5000$ & Moderate & $\begin{array}{l}\text { Any kind of shell material like } \\
\text { polysaccharides, proteins, } \\
\text { emulsifiers, fats, complex } \\
\text { formulations, enteric coating, } \\
\text { powder coatings, yeast cell } \\
\text { extract etc. }\end{array}$ \\
\hline
\end{tabular}

\section{SURVIVAL OF PROBIOTIC BACTERIA}

Covering of microcapsules with chitosan was found best in protecting probiotic microscopic organisms from the intestinal juice. Different variables were found to influence the viability of probiotic microorganisms in nourishment items amid handling, generation, and capacity as appeared in Fig 4. Krasaekoopt et al. (2004) reported that the probiotic microscopic organisms covered with alginate chitosan covering upgrade the feasibility and conveyance in the gastrointestinal tract. Various investigations of researchers portrayed that covering with chitosan gives the best security in bile salt. Murata et al. (1999), Koo et al. (2001), Krasaekoopt et al. (2004), Lee et al. (2004), Chavarri et al. (2010) demonstrated that the microencapsulated Lactobacillus casei and Lactobacillus gasseri surrounded with chitosan covering results in much reasonability as compare to microcapsules without covering with chitosan. Sultana et al., (2000) showed with the purpose of coating with alginate $L$. acidophilus and $L$. case diminished in log cycle as compared with the free cell by different bile salt concentrations. The preventive result of high amylose maize starch on the bile corrosive resistance was computed by Wang et al. (1999). It shows that amylomaize advance the suitability of probiotics with the different concentrations of bile and with the addition of starch granules. The gelatinized starch substance is utilized as the coating material for encapsulated probiotics. This swollen and gelatinized starch, along these lines, adds to expanding a consolidated structure (Slaughter et al., 2001 and Mohammadi et al., 2012). The reason for starch ge consolidates with chitosan covering is to enhance and grow the modern purposes. It has been postulated that the major reason for that is the microcapsules inundated in the bile salt and hence, the penetrability of bile salt in the microcapsules gets restricted. The different investigations demonstrated that the approach of prebiotics is better recovered with calcium alginate(Capela $\boldsymbol{e t}$ al., 2006, Homayouni et al., 2008, Nazzaroet al.,2009, Zanjani et al., 2012). In other research, it was observed that the microencapsulation method had a positive aftereffect of inulin in human medical studies (Capela et al., 2006 and Nazzaroet al., 2009).

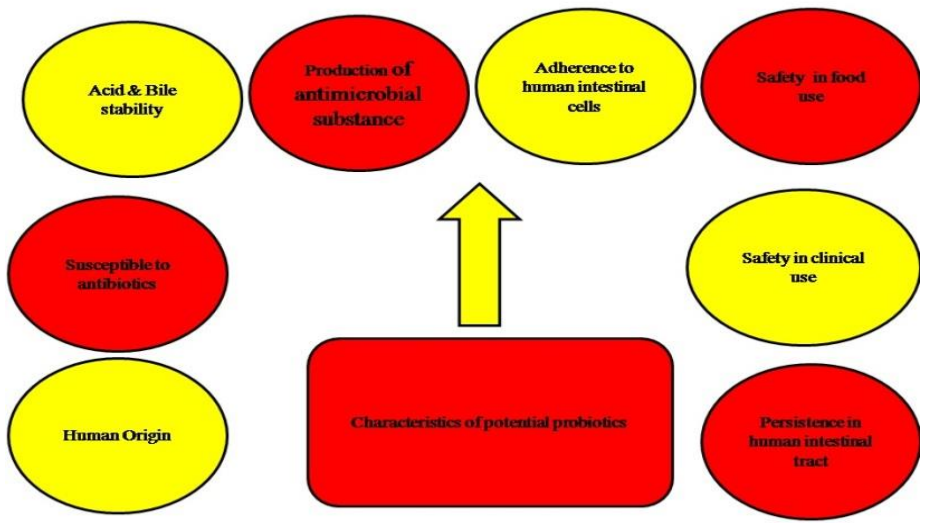

Figure 4 Various characteristics affecting the viability of probiotics in food products.

\section{SURVIVAL OF PROBIOTICS DURING PROCESSING AND STORAGE}

Development of foods with appropriate viability of probiotic as a result of many factors through out process and storage affect the stability of probiotic microorganisms (Korbekandi et al., 2011). Due to the high survival rate of probiotics enhance the stability of probiotic microorganism in food products
(Saxelin et al.,1999 and Cruz et al., 2010). Various endeavors have been made to enhance the feasibility of probiotics in various nourishment items amid their creation until the season of utilization. Numerous factors were found to impact the suitability of probiotic microorganisms in nourishment items amid creation, handling, and capacity. The distinguished variables incorporated in food products along with various parameters such as $\mathrm{pH}$, titratable acidity, oxygen, water activity, salt concentration, sugar and synthetic substances like hydrogen peroxide, bacteriocins, handling parameters (warm treatment, hatching temperature, cooling rate of the item, packing materials and capacity techniques, and size of capsule along with, microbiological parameters (strains of probiotics, rate and extent of inoculation) which helps in the enhancement of probiotic microorganisms.

\section{VARIABLES INFLUENCING SURVIVAL OF PROBIOTICS DURING PROCESSING}

\section{Fermentation conditions}

For influencing the viability of probiotic microorganisms fermentation temperature is one of the essential variables and other subjective parameters of probiotic food products with appropriate temperature ranges from $37-43^{\circ} \mathrm{C}$ (Boylston et al., 2004; Lee and Salminen, 2009 and Korbekandi et al., 2011) Despite the fact that at temperatures of $45^{\circ} \mathrm{C}$ the specific species of lactobacillus like L. acidophilus can grow, however, the ideal growth happens between 40-42 ${ }^{\circ} \mathrm{C}$. Temperatures above $45-50{ }^{\circ} \mathrm{C}$ have a negative impact on the survival rate of probiotic cultures. The arrangement time must be shorter at a higher temperature with the end goal to spare the probiotics (Lee and Salminen, 2009). Management to oxygen during aging assumes a noteworthy job in loss of feasibility of oxygen-sensitive microorganisms (Gaudreau et al., 2013). A few techniques have been utilized to diminish oxygen content during aging. The most essential one is achieving temperature under vacuum (Cruz et al., 2007). The obstruction of probiotic microscopic organisms to warm pressure can be expanded by gentle heat treatment preceding their utilization. Application of nonlethal heat shock enables microbes to tolerate pressure higher in force and it has been discovered that the heat adjustment builds the warm buoyancy of Lactobacilli (Teixeira et al., 1994). The study showed that the heat adjustment of live microorganisms preceding heat thrust has a positive impact to enhance the warm buoyancy of Lactococci and Lactobacilli with the untreated strains (Desmond et al., 2001).

\section{Solidifying and defrosting activities}

The earlier studies showed that different strains of probiotic microorganisms can survive in solidified items. The cell films of probiotics get harmed as a result of the solidifying process because of the mechanical burdens of the ice crystal formation in the intracellular and extracellular form of the cells. In these conditions, the solutes condensate and the cells get dried out results in amid solidifying. Thus, the crucial metabolic actions of the cells were decreased (Akin and Kirmaci, 2007). The rate of solidifying influences cell survival, as bigger ice crystals delivered by moderate solidifying cause more prominent harm to the cells and fast solidifying aides in better upkeep of the microorganisms in the item (Fowler and Toner, 2005; Gill, 2006; Mortazavian et al., 2011). Mortality additionally happens through defrosting of solidified items because of the presentation of the microbial cells to osmotic impacts and also to the high concentrations of hindering components such as hydrogen particles, natural acids, oxygen and other harming segments in liquefying media (Jay et al., 2005). 


\section{EXPANSION OF CELL PROTECTANTS}

In drying medium, the substances are added which facilitate in securing the practicality of probiotic cells. Some of those substances include skim powder, whey protein, glycerol, betaine, adonitol, lactose and polymers, for example, dextran (Hubalek, 2003). Perfect cryoprotectants as an example, glycerol was added to the medium for freeze-drying that helped within the regulation of probiotics to the adverse conditions by decreasing the osmotic characteristics (Capela et al., 2006). Desmond et al., 2002 utilized gum arabic (10\%) in the spray drying medium with an outlet temperature of $100-105{ }^{\circ} \mathrm{C}$ for upgrading probiotic survival of L.paracasei NFBC 338. The results showed less improved survival in gum arabic treated cells than the control cells. Skim protein in a reconstituted skim milk medium will stop the damage to the external covering of the cell and hence proved to be an appropriate medium for efficient spray drying of probiotic bacteria(Ananta et al.,2005). The reconstituted skimmed milk medium has the ability to form a protective covering on the proteins and use up calcium for survival after drying out (King and Su, 1993). In another experiment, the addition of polydextrose and inulin in the spray drying reconstituted skimmed milk medium did not improve the stability (Corcoran $\boldsymbol{e}$ al., 2005). The defensive effect of recipients on the spray drying and capacity was assessedSalar-Behzadi et al. (2013). Gum arabic and gelatin demonstrated the best defensive effect. Cells pre-treated with these biomaterials appeared diminished with upgraded reliability and along with multi-month of capacity time. It is expressed before that starches have defensive impacts for probiotic microscopic organisms intending to stop drying. They assist in raising the temperature and consequently creating a difference with free cells to attain the microencapsulated stage(Fowler and Toner, 2005). The safety of probiotics in smooth protein-starch relies upon the arrangement of the various factors (Hoobin et al., 2013). The incomplete substitution of maltodextrin with glucose (D-or L-) enhanced microbial survival at $33 \% \mathrm{RH}$ as a result of pointed sub-atomic versatility and lower water take-up. It has likewise been illustrated that trehalose is a good cryoprotectant used as a solidifying agent because of its good parameters with high change temperature, the solid ion-dipole associations and hydrogen bonding among trehalose and therefore the biomolecules allow higher survival of L. acidophilus (Conrad et al., 2000). Perfect solutes have additionally demonstrated useful in probiotic viability and safety in acidic conditions. Corcoran et al. (2004) found that the concentration of $19.4 \mathrm{mM}$ glucose brought about up to 6-log improved survival following 90 min enhanced the stability of probiotic bacteria in digestive juice at $\mathrm{pH} 2.0$ as analyzed to the control Santivarangkna et al. (2006) detailed that the survival of L. helveticus under vacuum drying was the best method by the increase of $1 \%$ sorbitol.

\section{APPLICATIONS OF ENCAPSULATION IN THE FOOD INDUSTRY}

Microencapsulation method is broadly utilized in different fields, essentially food industries, since; it can upgrade strength, increase dissolvability and enhance the properties of probiotic products, for example, cancer prevention agents and chemicals. The food industries use fundamental components to enhance texture, flavor, surface, and timeframe of the realistic usability of items. The principa objective in the food is to create a high-productivity microcapsule with an ease generation. Despite the fact that a more wide-time of genera and types of different probiotic microorganisms are considered as potential probiotics. The principal microbes from the genera Lactobacillus and Bifidobacterium are economically utilized in probiotic food items is clearly seen from Table 2 (Shah and Ravula, 2004). Further, the cells of various probiotic life forms were epitomized and conceivably utilized in various sustenances and biotechnological applications (Table 3). In the field of food innovation relatively few investigations detailed for the embarrassment of live microorganism in dairybased items and protein microcapsules, because of the reason of heat-sensitive and gelation of food based protein. Hence, heat treatment was not found for heat sensitive barrier or center materials like live organisms (Chen et al., 2006). The healthful and practical estimation of proteins of grains (oat, wheat, grain, and corn) is more gainful for production reason and their vital useful properties or different food applications and hence, these proteins were used as a biomaterial for microencapsulation (Ducelet al., 2004 and Nur, 2010).
Table 2 Commonly used species of lactic acid bacteria in probiotic preparation

\begin{tabular}{ll}
\hline Probiotic bacteria & \multicolumn{1}{c}{ Species } \\
\hline Lactobacillus $\mathrm{sp}$. & L. acidophilus, L. casei, \\
& L. delbrueckii ssp., \\
& L. cellobiosus, L. curvatus, \\
& L. fermentum, L. lactis, \\
& L. plantarum, L. reuteri, \\
Bifidobacterium sp. & B. bifidum, B. adolescentis, \\
& B. animalis, B. infantis, B. thermophilum, B. Longum \\
Enterococcus sp. & Ent. faecalis, Ent. faecium \\
Streptococcus $\mathrm{sp}$. & S. cremoris, S. salivarius, \\
& S. diacetylactis, S. Intermedius
\end{tabular}

Source: Shah and Ravula, 2004.

\section{MICROENCAPSULATION AND RELEASE OF PROBIOTICS}

Microencapsulation is a technique characterized for the entrapment of a compound or a substance (active agent) into another substance (wall material) for its grip, safety, controlled discharge and its structural function (Poncelet, 2006). The core or payload of the microcapsule is the encapsulated active substance in microencapsulation where the active agent is known as coating or carrier material. The wide range of substances can be utilized by microcapsules: solids, fluids, drugs, proteins, bacterial cells, undifferentiated cells. Due to a huge scope of free substances, microcapsules can have a combination of goals and applications in health. Regardless of whether for medication conveyance, catalys recovery and simulation of cells and artificial organ conveyance and as depicted in this review, for the conveyance of live probiotic microorganisms. There is a number of microcapsule conveyance frameworks that have been proposed for the oral intake of live bacterial cells. In 2000, Sun and Griffiths explored the utilization of an acidic stable capsule composed of gellan and xanthan gum for the control of the Bifidobacterium release. The results showed that capsulated cells survived altogether superior to the free cells after refrigeration in purified yogurt for a maximum time of 5 weeks. The use of calcium alginate as a polymer for microencapsulation is the normal strategy. In case the utilization of alginate is troublesome as these are not safe and due to low $\mathrm{pH}$ conditions experienced in the stomach, they show critical shrinkage and a decline in mechanical quality and their passage (Krasaekoopt et al., 2004). Various techniques using polymer cross-connection have been proposed for microencapsulation by utilizing carrageenan, alginate-poly-L-lysine, starch polyanhydrides, polymethacrylates, and enteric covered polymers. Microencapsulation techniques are being created and enhanced to take account for expanded gastrointestinal survival and immunoprotection in the tract. One recently created kind of microcapsule that showed promising outcomes in terms of mechanical solidness and $\mathrm{pH}$ obstruction is cross-linked- alginate-chitosan microcapsules. The most ordinarily used plans for microencapsulation are the alginate-poly- L-lysine-alginate (APA) microcapsule for micro-coating (Prakash and Chang, 1996). APA sort of microcapsule has been utilized for various applications including drugs, undifferentiated organisms, and bacterial cell delivery. This technique depends on the polyelectrolyte complexation instrument for the association of the polymers to the alginate and poly-L-lysine (PLL). Alginate is a normal occurring biocompatible polymer extracted from brown-green algae that are progressively utilized in the field of biotechnology for extensive uses. Alginate is an unbranched polysaccharide which contains 1, 4 - connected $\beta$-D-mannuronic acid and $\alpha$-L-guluronic acid chain which are inter-dispersed with areas of the substituting structure of $\beta$-L-mannuronic and $\alpha$-L-guluronic chain (Haug and Larsen, 1962). PLL is a polypeptide of amino acid, L-lysine that is accessible in a variable number of chain lengths, defined by its sub-atomic weight. It is a polycationic polymer that can be utilized for covering the venture of microencapsulation. The expansion of polycationic polymer prompts the development of a product that gives particular penetrability and immunoprotection to the microcapsules. The alginate bead cannot withstand the harsh condition of the gastrointestinal tract without PLL, which furnishes it with an extended mechanical safety and targeted delivery.

Table 3 Different food applications of encapsulated microorganism

\begin{tabular}{|c|c|c|c|}
\hline Microorganism & Encapsulation material & Food & Reference \\
\hline B. bifidum, B. Infantis & Calcium alginate & Mayonnaise & Khalil; Mansour 1998 \& Kasipathy Kailasapathy, 2002 \\
\hline L. paracasei & Milk fat & Cheddar cheese & Stanton et al., 1998 \\
\hline Enterococcus faecium & Milk fat & Cheddar cheese & Gardiner et al., 1998 \& Kasipathy Kailasapathy, 2002 \\
\hline B. bifidum, B. adolescentis and B.breve & Cream & White brined cheese & Ghoddusi and Robinson, 1998; Cook et al., 2014 \\
\hline B. bifidum, B. infantis, and B. Longum & Calcium alginate gels & Crescenza cheese & Gobbeti et al., 1997 \& Chavarri et al., 2010 \\
\hline L. lactis & $\begin{array}{l}\text { k-Carrageenan and locust } \\
\text { bean gum }\end{array}$ & Fresh cheese & Sodini et al., 1997 \\
\hline L. casei & Liquid core alginate capsule & Fresh cheese & Li et al., 2011 \\
\hline Lactobacilli & Calcium alginate & Frozen ice cream & Sheu and Marshall, 1993 \\
\hline Lactobacillus acidophilus & Calcium alginate & White brined cheese & Ozer et al., 2009 \\
\hline
\end{tabular}




\section{MICROENCAPSULATED PROBIOTICS}

In the field of microencapsulated probiotics, the interest rate has been increased in recent years. Microencapsulated probiotics keep their practicality finer to free cells under concern in gastrointestinal conveyances; this has been demonstrated by recent research. Microencapsulated probiotics provide promising results for the usual treatment of various gastrointestinal infections, increases gut microflora and hence is very useful for maintaining the balance of the digestive system.

\section{Microencapsulated Probiotics and Colon Cancer}

The microencapsulated L. acidophilus was examined for antitumorigenic properties in different intestinal neoplasia mice assigning a germline APC change which, treats various pretumoric intestinal neoplasms (Urbanska, 2009). The mice were injected with APA L. acidophilus microencapsulates for a duration of 12 weeks pursued with the identification, grouping and the histopathology of adenomas. No huge difference was observed between the treated and control group of immense intestinal adenomas. In addition, there was a measurable difference between the control and treatment study of the digestive tract, furthermore, resulting in the treatment of gastrointestinal intraepithelial neoplasias. This study on mice results in effective colon growth with the help of microencapsulated probiotic microorganisms.

\section{Microencapsulated Probiotics for Use in Cardiovascular}

Microencapsulated probiotic microorganism lowers the cholesterol level in humans. Previous research has shown that specific species of Lactobacilli have a bile salt hydrolase (BSH) chemical which can add and results in cholesterol level down impact in vivo in cardiovascular infections (Anderson and Gilliland, 1999). This chemical adds to the deconjugation of bile salts in the digestive tract The oral conveyance of Lactobacillus has, in this way, rose as a potential component for actuating cholesterol bringing down. Martoni and Prakash, 2008 showed that microencapsulated BSH-dynamic microscopic organisms can make due in a reenacted human gastrointestinal demonstrate while keeping up cell practicality and catalyst action, which would not be conceivable with the immediate conveyance of non-microencapsulated bacterial cells. Another microencapsulated probiotic Lactobacillus containing feruloyl esterase protein helps in bringing down the hypercholesterolemic activities (Bathena et al., 2009). Hypercholesterolemic mice were injected with Lactobacillus fermentum, twice every day by oral dose, for a time of 18 weeks and further histological investigations were additionally performed which showed that the microencapsulated probiotic reduces the progress of atherosclerotic injuries in the mice and was subsequently appeared to be viable in controlling the serum cholesterol and triglyceride level. The study evaluated that the microencapsulation of probiotics is very helpful for the improvement of cardiovascular diseases. Microencapsulation can possibly be valuable in other applications. It has been demonstrated that Lactobacillus acidophilus affected colon tumorigenesis colonize the probiotic microorganism in the gastrointestinal tract which is helpful in solving the problem of tumorigenesis. Therefore, the viability is vital to the activity of the probiotic organism ingested and survived by $1 \%$ in the gastric environment, regulating the impact of orally conveyed bacteria microorganisms. Microencapsulation shows the beneficial increase in viability with protected probiotic microorganisms (Pool, 1996).

\section{CONCLUSION}

Encapsulation is one of the most emerging technologies and has the ability to enhance the shelf life of food products further, providing consumers with convenient and healthier foods. Although, on a laboratory scale various technologies exists for encapsulation are efficient but on a large scale, it is very difficult to produce microencapsulated microorganisms of food grade. In the present article, the important strategies utilized in the epitome of probiotic cells are discussed. The survival of cells can be enhanced by the microencapsulation of probiotic microorganisms in calcium alginate-gelatinized starch with the covering of chitosan after re-sanctioned in gastrointestinal condition when appeared differently in relation to free cells. Further, microencapsulation can be used for increasing the survivability of probiotic bacteria in the food matrix. Biomaterials utilized in the encapsulation techniques such as calcium alginate, gellan gum; xanthan and starch provide a smooth surface to the final functional food. Along these lines, the connected methodology in this review may demonstrate value for the conveyance of probiotic microbes to the reproduced individual gastrointestinal tract.

Conflict of interest: There is no conflict of interest among the authors. The authors are solely responsible for the content of this article.

\section{REFERENCES}

AKIN, M. B., AKIN, M. S., KIRMACI, Z. (2007).Effects of inulin and sugar levels on the viability of yogurt and probiotic bacteria and the physical and sensory characteristics in probiotic ice cream. Food Chemistry, 104, 93-99. http://dx.doi.org/10.1016/j.foodchem.2006.11.030

AMMOR, M.S, FLOREZ, A.B, MAYO, B. (2007). Antibiotic resistance in nonenterococcal lactic acid bacteria and bifidobacteria. Food Microbiology,24, 55970.http://dx.doi.org/10.1016/j.fm.2006.11.001

ANDERSON, J. W., GILLILAND, S. E., (1999). Effect of fermented milk (yogurt) containing Lactobacillus acidophilus L1 on serum cholesterol in hypercholesterolemic humans. Journal of the American College of Nutrition, 18, 43-50.

ANTUNES, A.C.E., LISERRE, A.M., COELHO, A.L.A., MENEZES, C.R., MORENO, I., YOTSUYANAGI, K., AZAMBUJA, N.C.(2013).Acerola nectar with added microencapsulated probiotic. LWT - Food Science Technology 54, 125-131.http://dx.doi.org/10.1016/j.lwt.2013.04.018

APARNA, K. (2010). Microencapsulation Technology- A Review Nutriplus International crop research institute. Journal of Research, 38, 86-102.

AUDET, P., PAQUIN, C., LACROIX, C. (1988). Batch fermentation with entrapped cells of Lactobacillus casei: optimization of the rheological properties of the entrapment gel matrix. Applied Microbiology Biotechnology, 32, $403-$ 408.http://dx.doi.org/10.1007/s11274-004-4735-2

BHATHENA, J., MARTONI, C., KULAMARVA, A., URBANSKA, A. M., MALHOTRA, M., PRAKASH, S. (2009). Orally delivered microencapsulated live probiotic formulation lowers serum lipids in hypercholesterolemic hamsters," Journal of Medicinal Food, 12, 310-319. http://dx.doi.org 10.1089/jmf.2008.0166.

BOYLSTON, T. D., VINDEROLA, C. G., GHODDUSI, H. B., \&REINHEIMER, J.A. (2004). Incorporation of Bifidobacteria into cheeses: Challenges and rewards.International Dairy Journal, 14, 375387.http://dx.doi.org 10.1089/jmf.2008.0166.

BURGAIN, GAIANI, LINDER, \&SCHER. (2011). Encapsulation of probiotic living cells: from laboratory scale to industrial applications. Journal of Food Engineering, 104, 467-483.http://dx.doi.org/10.10.1016/j.jfoodeng.2010.12.031

CAPELA, P., (2006). Use of cryoprotectants, prebiotics and microencapsulation of bacterial cells in improving the viability of probiotic organisms in freeze-dried yogurt, in School of Molecular Science, Victoria University, 39, 203 211.http://dx.doi.org/10.1016/j.foodres.2005.07.007

CAPELA, P., HAY, T. K. C., \& SHAH, N. P. (2005). Effect of cryoprotectants, prebiotics, and microencapsulation on the survival of probiotic organisms in yogurt and freeze-dried yogurt. Food Research International, 39, 203 211.http://dx.doi.org/10.1016/j.foodres.2005.07.007

CHAMPAGENE, C. P., \& FUSTIER, P. (2007). Microencapsulation for delivery of probiotics and other ingredients in functional dairy products. Functional Dairy Products,2, 404-426. http://dx.doi.org/10.1533/9781845693107.3.404

CHAVARRI, M., MARANON, I., ARES, R., IBANEZ, F.C., MARZO, F., VILLARAN, C. (2010). Microencapsulation of a probiotic and prebiotic in alginate-chitosan capsules improves survival in simulated gastro-intestinal conditions. International Journal FoodMicrobiology,142, 189.http://dx.doi.org/10.1016/j.ijfoodmicro.2010.06.022

CHAVARRI, M., MARAONN, I., ARES, R., IBANEZ, F. C., MARZO, F., VILLARAN M. D. C. (2010). Microencapsulation of a probiotic and prebiotic in alginate-chitosan capsules improves survival in simulated gastro-intestinal conditions. International Journal Food Microbiology,142, 185-189. http://dx.doi.org/10.1016/j.ijfoodmicro.2010.06.022

CHEN, M. J., CHEN, K. N. (2007). Applications of probiotic encapsulation in dairy products. In: lakkis, Jamileh M. (Ed.). Encapsulation and Controlled Release Technologies in Food Systems,4, 83-112. http://dx.doi.org/ $10.5772 / 50046$

COOK, M. T., TZORTZIS, G., CHARALAMPOPOULOS, D., \&KHUTORYANSKIY V. V. (2012). Microencapsulation of probiotics for gastrointestinal delivery.Journal of Controlled Release, 162, 56-67. http://dx.doi.org/10.1016/j.jconrel.2012.06.003

COOK, M.T., TZORTZIS, G., CHARALAMPOPOULOS, D. KHUTORYANSKIY, V.V. (2014). Microencapsulation of a synbiotic into PLGA/alginate multiparticulate gels. International Journal Pharmaceutics, 466, 400-408. http://dx.doi.org/ 10.1016/j.ijpharm.2014.03.034

CRUZ, A. G., FARIA, J. A. F., SAAD, S. M. I., BOLINI, H. M. A., SANT'ANA A. S., CRISTIANINI, M. (2010). High-pressure processing and pulsed electric fields: Potential use in probiotic dairy foods processing. Trends in Food Science \& Technology, 21, 483-493.http://dx.doi.org/10.1590/1678-457X.6833

Desmond, C., STANTON, C., FITZGERALD, G. F., COLLINS, K., ROSS, R. P (2001).Environmental adaptation of probiotic Lactobacilli towards improved performance during spray drying. International Dairy Journal, 11, 801-808. http://dx.doi.org/10.1128/AEM.71.6.3060-3067.2005

DE, KRUIF, C.G., WEINBRECK, F., DE, VRIES, R. (2004). Complex coacervation of proteins and anionic polysaccharides. Current Opinion Colloid Interface Science, 5, 340-349.http://dx.doi.org/10.1021/bm025667n

DOHERTY, S.B., AUTY, M.A., STANTON, C., ROSS, R.P., FITZGERALD, G.F., BRODKORB, A. (2012). Application of whey protein micro-bead coatings for enhanced strength and probiotic protection during fruit juice storage and gastric incubation. Journal Microencapsulation, 29, 713 28.http://dx.doi.org/10.3109/02652048.2011.638994 
FANG, Z., BHANDARI, B. (2010). Encapsulation of polyphenols - a review. Trends in Food Sciences \& Technology, 21, 510523.https:doi.org/10.1016/j.tifs.2010.08.003

FOWLER, A., TONER, M. (2005). Cryo-injury and biopreservation. Annals of New York Academy of Sciences, 1066, 119135.http://dx.doi.org/10.1196/annals.1363.010

GARDINER, G., ROSS, R. P., COLLINS, J. K., FITZGERALD, G. STANTON, G. (1998).Development of a probiotic cheddar cheese containing human-derived Lactobacillus paracasei strains. Applied Environment Microbiology, 64, 21922199.

GAUDREAU, H., CHAMPAGNE, C. P., REMONDETTO, G. E., BAZINET, L., SUBIRADE, M. (2013).Effect of catechins on the growth of oxygen-sensitive probiotic bacteria. Food Research International, 53, 751-757. http://dx.doi.org/10.10s13594-014-0165-6

GBASSI, G. K., VANDAMME, T. (2012). Probiotic encapsulation technology: from microencapsulation to release into the gut. Pharmaceutics, 4, 149-163. http://dx.doi.org/10.3390/pharmaceutics 4010149

GIBSON, G. R., ROBERFROID, M. B. (1995).Dietary modulation of the human colonic microbiota: introducing the concept of prebiotics. Journal of Nutrition 125, 1401-12.http://dx.doi.org/10.1093/jn/125.6.1401

GILL, C. O. (2006).Microbiology of frozen foods. In S. Da Wen Boca (Ed.), Handbook of frozen food processing and packaging pp. 85-100. Boca Raton, FL: CRC Press.https://www.routledgehandbooks.com/pdf/doi/10.1201/b11201

GISMONDO, M. R., DRAGO, L., LOMBARDI, A. (1999). Review of probiotics. International Journal Antimicrobial Agents, 12, 287-292.

GOBBETTI, M., CORSETTI, A., SMACCHI, E., ZOCCHETTI, A., ANGLEIS, M. (1997). Production of crescenza cheese by the incorporation of bifidobacteria.Journal Dairy Sciences, 81, 37-47.

GOH, C., HIAN, H., PAUL, W., SIA, C., LAI W.(2012). Alginates as a useful natural polymer for microencapsulation and therapeutic applications.Food and Agriculture Organization of the United Nations,88, 112.http://dx.doi.org/10.1016/j.carbpol.2011.11.02

GUPTA, C., CHWALA, P., ARORA, S., TOMAR, S.K., SINGH, A.K. (2015). Iron microencapsulation with the blend of gum arabic, maltodextrin and modified starch using modified solvent evaporation method- Milk fortification. Food Hydrocolloids, 43, 622-628. http://dx.doi.org/10.1016/j.foodhyd.2014.07.02110 HARALAMPU, S. G., (2000). Resistant starch-a review of the physical properties and biological impact. Carbohydrate Polymers, 285 292.https://onlinelibrary.wiley.com/doi/pdf/10.100.1002/star.201000099

HAUG, A., LARSEN, B. (1962).Quantitative determination of the uronic acid composition of alginates. ActaChemicaScandinavica, vol. 16, no. 8, pp. 19081918.

HOLKEM, A. T., RADDATZ, G. C., BARIN, J. S., FLORES, E. M. M., MULLER, E. I., CODEVILLA, C. F., DE MENEZES, C. R. (2017). Production of microcapsules containing BifidobacteriumBB-12 by emulsification/internal gelation. LWT-Food Science and Technology, 76, 216-221. http://dx.doi.org/10.3390/ijms19010150

HOMAYOUNI, A., AZIZI, A., EHSANI, M. R., YARMAND, M. S., RAZAVI, S. H. (2008).Effect of microencapsulation and resistant starch on the probiotic survival and sensory properties of symbiotic ice cream. Food Chemistry Industrial Biotechnology, 18 ,

61.http://dx.doi.org/10.1016/j.fmoodchem2008.03.036

JACKSON L. S., LEE K (1991). Microencapsulation andthe food industry, Lebennsmittel- WissenschaftTechonologie. Retrieved on 1991-02-02. https://doi.org/10.1111/j.1365-2621.1991.tbl14638x

JAIN, N.K. (2002).Controlled and Novel Drug Delivery, 4th edition, 236-237.

KASTURAGI, Y., SUGIURA, Y.C., LEE, K., OTSUGI, KURIHARA, (1995)

Selective Inhibition of Bitter Taste of Various Drugs By Lipoprotein. Pharmaceutical Research 12, 658-662.

KHALIL, A. H., MANSOUR, E.H. (1998). Alginate encapsulated bifidobacteria survival in mayonnaise. Journal Food Sciences, 63, 702-705. https://doi.org/10.1111/j.1365-2621.1998.tb15817x

KIM, J. U., KIM, B., SHAHBAZ, H. M., LEE, S. H., PARK, D., PARK, J. (2016). Encapsulation of probiotic Lactobacillus acidophilus by ionic gelation with electrostatic extrusion for enhancement of survival under simulated gastric conditions and during refrigerated storage. International Journal of Food Science and Technology, 52, 519-530.https:doi.org/10.1111/ijfs.13308

KING, A. H. (1995). Encapsulation of Food ingredients: a review of available technology, focusing on hydrocolloids. In: S.J. Risch and. Reineccius (Eds.) Encapsulation and controlled release of food ingredients, Washington DC. American Chemical Society, 213-220.https://pubs.acs.org/doi/abs/10.1021/bk195-0590

KITAMURA, Y., ITOH, H., ECHIZEN, H., SATAKE, T. (2009). Experimental vacuum spray drying of probiotic foods included with lactic acid bacteria Journal Food Processing Preservation, 33, 714-726. https:doi.org/10.1111/j.1745-4549.2008.00299x

KLEIN, J., VORLOP, D.K. (1985).Immobilization techniques cells. In Comprehensive Biotechnology, 542-550.

KOO, S., CHO, Y., HUH, C., BAEK, Y., PARK, J. (2001).Improvement of the stability of Lactobacillus caseiby microencapsulation using alginate and chitosan.
Journal Microbiology Biotechnology, 11, 376-383. https:doi.org/10.3389/fmicb.2016.00494

KORBEKANDI, H., MORTAZAVIAN, A. M., IRAVANI, S. (2011).Technology and stability of probiotic in fermented milk. In N. Shah, A. G. Cruz, \& J. A. F. Faria (Eds.), Probiotic and prebiotic foods: Technology, stability, and benefits to human health (pp.131-169).New York: Nova Science Publishers.http://dx.doi.org/10.1007/s13197-014-1516-2

KRASAEKOOPT, W., BHANDARI, B., DEETH, H. (2004). The influence of coating materials on some properties of alginate beads and survivability of microencapsulated probiotic bacteria International Dairy Journal, vol. 14, no. 8 , pp. 737-743. https://doi.org/10.1016/j.idairyj.diaryj.2004.01.04

KRASAEKOOPT, W., BHANDARI, B., DEETH, H., (2003). Evaluation of encapsulation techniques of probiotics for yogurt. International Dairy Journal,13, 3-13. http://dx.doi.org/10.1016/S0958-6946(02)00155-3

KRUIF, C. G., WEINBRECK, F., E VRIES, R. (2004). Complex coacervation of proteins and anionic polysaccharides. Current Opinion in Colloid and Interface Science, 9, 340-349. https://pubs.acs.org/doi/10.1021/bm025667n

LACROIX. C., PAQUIN, C., ARNAUD, J.P. (1990).Batch fermentation with entrapped growing cells of Lactobacillus casei. Optimization of the rheological properties of the entrapment gel matrix. Applied Microbiology Biotechnology, 32, 403-408.http://dx.doi.org/10.1128/AEM.71.12.8165-8173.2005

LANKAPUTHRA, W. E. V., SHAH, N. P. (1995). Survival of Lactobacillus acidophilus and Bifidobacteriumspp.in the presence of acid and bile salts. Cult. Dairy Production Journal, 30, 2-7.

LAOHASONGKRAM, K., MAHAMAKTUDSANEE, T., CHAIWANICHSIRI, S. (2011). Microencapsulation of Macadamia oil by spray drying. Procedia Food Science, 1, 1660-1665. http://dx.doi.org/10.1016/j.profoo.2011.09.245

LEE, J. S., CHA, D. S., PARK, H.J. (2004).Survival of Freeze-Dried Lactobacillus bulgaricusKFRI 673 in Chitosan-Coated Calcium Alginate Microparticles. Journal Agriculture Food Chemistry, 52, 73007305.http://dx.doi.org/10.1021/jf040253k

LI, x.., CHEN, X.G., SUN, Z.W., PARK, H.J., CHA, D.S. (2011). Preparation of alginate, chitosan complex microcapsules and application in Lactobacillus case ATCC 393. Carbohydrate Polymer 83, 14791485.http://dx.doi.org/10.3390/nu7020831

MARTINSEN, A., SKJAK-BRAEK, C., SMIDSROD. (1989). Alginate as immobilization material: correlation between chemical and physical Biotechnology Bioengineering, 5, 79-89. http://dx.doi.org/10.1002/bit260330111 MARTONI, C., BHATHENA, J., URBANSKA, A. M., PRAKASH, S. (2008) Microencapsulated bile salt hydrolase producing Lactobacillus reuterifor oral targeted delivery in the gastrointestinal tract. Applied Microbiology and Biotechnology, vol. 81, no. 2, pp. 225-233. http://dx.doi.org/10.1007/s00253008-1642-8

MOHAMMADI, N., AHARI, H., FAHIMDANESH, M., ZANJANI M. A. K. ANVAR, A., SHOKRI, E. (2012). Survival of alginate-prebiotic microencapsulated Lactobacillus acidophilus in mayonnaise sauce. Iranian Journal of Veterinary Medicine, 6, 259-264.

MORTAZAVIAN, A., RAZAVI, S. H., EHSANI, M. R., SOHRABVANDI, S. (2007). Principle and method of microencapsulation of probiotic microorganisms.Iranian Journal of Biotechnology, 5, 1-18.

MORTAZAVIAN, A., SOHRABVANDI, S., MOHAMMADI, R (2012).Delivery of probiotic microorganisms into gastrointestinal tract by food products.New advances in the basic and clinical gastroenterology, 59, 123-127. http://dx.doi.org/10.5772/47946

MUNIN, A., EDWARDS, L. (2011). Encapsulation of natural polyphenolics compounds. Journal of Pharmaceutics, 4, 793-829. http://dx.doi.org10.3390/pharmaceutics3040793

MURATA, Y., TONIWA, S., MIYAMOTO, E., KAWASHIMA, S. (1999) Preparation of alginate gel beads containing chitosan salt and their function. International Journal Pharmaceutics, 176, 265268.http://dx.doi.org/10.1016/SO378-5173(98)00308-1

NAZZARO, F., FRATIANNI, F., COPPOLA, R., SADA, A., ORLANDO, P (2009). The fermentative ability of alginate-prebiotic encapsulated Lactobacillus acidophilus and survival under simulated gastrointestinal conditions. Journal Functional Foods, 1, 319-323. http://dx.doi.org/10.1016/j.jff.2009.02.001

NIHANT, N., GRANDFILS, C., JEROME, R. (1995). Microencapsulation by coacervation of poly (lactide-co-glycolide): Effect of the processing parameters on coacervation and encapsulation. Journal of Controlled Release, 35, 117-12. https://doi.org/10.1016/0168-3659(95)00026-5

OZER, B., KIRMACI, H.A., SENEL, E., ATAMER, M., HAYALOGLU, A. (2009). Improving the viability of Bifidobacteriumbifidum BB-12 and Lactobacillus acidophilus LA-5 in white-brined cheese by microencapsulation $\begin{array}{llll}\text { International Dairy } & \text { Journal, } & 1,29\end{array}$ http://dx.doi.org/10.1016/j.idiaryj.2008.07.00

PIANO, STROZZI, M., BARBA, P., ALLESINA, M., DEIDDA, S. LORENZINI, F., MORELlI, P., CARMAGNOLA, L., PAGLIARULO, S., BALZARINI, M., BALLARE, M., ORSELLO, M., MONTINO, M. SARTORI, F., GARELLO, M., CAPURSO, L. (2008). In vitro sensitivity of probiotics to human pancreatic juice.Journal Clinical Gastroenterol, 42, 170173. https://doi.org/10.1016/S1590-8658(07)60004-8 
PONCELET, D. (2006). Microencapsulation: fundamentals, methods, and applications, in Surface Chemistry in Biomedical and Environmental Science, pp. 23-34, Springer, Amsterdam, The Netherlands.https://doi.org/10.1007/1-40204741-X_3

POOL-ZOBEL, B. L., NEUDECKER, C., DOMIZLAFF.(1996). Lactobacillus and bifidobacterium-mediated antigen toxicity in the colon of rats.Nutrition and Cancer, vol. 26, no. 3, pp. 365-380. https//doi.org/10.1079/BJN20041161

POSHADRI, A., \& KUNA, A., (2010). Microencapsulation technology: A review. JournalResource of ANGRAU, 38, 86-102.

PRAKASH, S., \& CHANG, T. M. S. (1996). Microencapsulated genetically engineered E. coli DH5 cells for plasma urea and ammonia removal based on 1. Column bioreactor and 2.Oral administration in uremic rats. Artificial Cells, Blood Substitutes, and Immobilization Biotechnology, vol. 24, no. 3, pp. 201218, 1996. http://dx.doi.org/10.1155/2010/620827

PREVOST, H., DIVIES, C. (1992). Cream fermentation by a mixed culture of lactococci entrapped in two-layer calcium alginate gel beads. Biotechnology Letter, 14, 583-588. http://dx.doi.org/10.1016/S0958-6946(02)00155-3

RASIC, J. L. (2003). Microflora of the intestine probiotics.In: B.Caballero, L. Trugo, and P. Finglas (Eds.), Encyclopedia of food sciences and nutrition, 3911 3916.

RIVEROS, B., FERRER, J., BORQUEZ, R. (2009). Spray-drying of a vagina probiotic strain of Lactobacillus acidophilus. Drying Technology, 27, 123-132. http://dx.doi.org/ 10.1080/0737393802566002

ROKKA, S., RANTAMAKI, P. (2010). Protecting probiotic bacteria by microencapsulation: Challenges for industrial applications. European Food Research Technology, 231, 1-12. https://link.springer. /10.1007/s00217com /article -010-1246-2

SANDILE, M., RODERICK, B. (2017).Science and practice of microencapsulation technology.Advances in Delivery Science and Technology, 119-154. https://link.springer.com/chapter/10.1007/978-1-4939-7012-4

SHAH, N. P., \& RAVULA, R. (2004).Selling the cells in desserts.DairyIndustries $\quad$ International, $\quad 69, \quad 31-32$ https://doi.org/10.1016/j.ff.2017.09.026

SHEU, T.Y., MRASHALL, R.T. (1993). Microencapsulation of lactobacilli in calcium alginate gels. Journal of Food Sciences, 54, 557561.https://doi.org/10.1111/j.13652621.1993.tb0423x

SLAUGHTER, S.L., ELLIS, P.R., BUTTERWORTH, P.J. (2001).An investigation of the action of porcine pancreatic alpha-amylase on native and gelatinized starches. Biochemistry Biophysics, 1525, 29 36.https://doi.org/10.1016/j.foodchem.2018.03.017

SODINI, I., BOQUIEN, C. Y., CORRIEU, G., LACROIX, C. (1997).Use of an immobilized cell bioreactor for the continuous inoculation of milk in fresh cheese manufacturing. Journal of Dairy Sciences, 12, 53615373.https://doi.org/10.3168/j.ds.2007-0273

STANTON, C., GARDINER, G., LYNCH, P. B., COLlINS, J. K., FITZGERALD, G., ROSS, R. P.(1998). Probiotic cheese.International Dairy Journal,8, 491-496.https://doi.org/10.1016/S0958-6946(98)00080-6

SULLIVIAN, O., D. J. (2005). Primary sources of probiotic cultures. In: I. Goktepe, V.K. Juneja, and M. Ahmedna. (Eds.). Probiotics in food safety and human health. Boca Raton: Taylor \& Francis, 89105.http://dx.doi.org/10.1590/0103-8478cr20140938

SULTANA, K., GODWARD, G., REYNOLDS, N., ARUMUGASWAMY, R. PEIRIS, P., KAILASAPATHY, K. (2000).Encapsulation of probiotic bacteria with alginate-starch and evaluation of survival in simulated gastrointestinal conditions in yogurt.International Journal of Food Microbiology, 62, 47-55. http://dx.doi.org/10.1016/j.ijfoodmicro.2010.06.022

SUN, W., GRIFFITHS, M. (2000). Survival of bifidobacteria in yogurt and simulated gastric juice following immobilization in gellan-xanthan beads. International Journal of Food Microbiology, vol. 61, no. 1, pp. 1725.http://dx.doi.org/10.1016/S0168-1605(00)00327-5

TANAKA, H., MASATOSE, M., VELEKY, I. (1984). Diffusion characteristics of substrates in calcium-alginate beads. Biotechnology Bioengineering, 26, 53-58. TEIXEIRA, P., CASTRO, H., KIRBY, R. (1994). Inducible thermotolerance in Lactobacillus bulgaricus.Letters in Applied Microbiology, 18, 218-221. http://dx.doi.org/10.1111/j.1472-765X.1994.tb00851.x

THEODORAKOPOULOU, M., PERROS, E., GIAMARELLOSBOURBOULIS, E. J., DIMOPOULOS, G. (2013). Controversies in the management of critically ill: the role of probiotics. International Journal Antimicrobial Agents, 42,

44.https://doi.org.10.1016/j.ijantimicag.2013.04.010

TOLUN, A., ALTINTAS, Z., ARTIK, N. (2016). Microencapsulation of grape polyphenols using maltodextrin and gum arabic as two alternative coating materials: Development and characterization.Journal of Biotechnology, 239, 23 33. http://dx.doi.org/10.1016/j.jbiotec.2016.10.001

TRUELSTRUP-HANSEN, L., ALLAN-WOJTAS, P. M., JIN, Y. L., PAULSON, A. T. (2002). Survival of free and calcium-alginate microencapsulated Bifidobacterium spp. In simulated gastrointestinal conditions.Food Microbiology, 19, 35-45.https://doi.org/10.1006/fmic.2001.0452 URBANSKA, A. M., BHATHENA, J., MARTONI, C., PRAKASH, S.,(2009).Estimation of the potential antitumor activity of microencapsulated
Lactobacillus acidophilus yogurt formulation in the attenuation of tumorigenesis in Apc mice. Digestive Diseases and Sciences, vol. 54, no. 2, pp. 264273.http://dx.doi.org/10.4061/2010/894972

WANG, X., BROWN, I. L., EVANS, A. J., CONWAY, P. L. (1999). The protective effects of high amylose maize (amylomaize) starch granules on the survival of Bifidobacteriumspp. in the mouse intestinal tract. Journal Applied. Microbiology, 87, 631-639. https://doi.org/10.1046/j.1365-2672.1999.00836.x

YOO, I. K., SEONG, G. H., CHANG, H. N., PARK, J. K. (1996). Encapsulation of Lactobacillus casei cells in liquid-core alginate capsules for lactic acid production. Enzyme Microbial Technology, 19, 428-433.

ZANJANI, M. A. K., TARZI, B. G., SHARIFAN, A., MOHAMMADI, N., BAKHODA, H., MADANIPOUR, M. (2012).Microencapsulation of Lactobacillus caseiwith calcium alginate-resistant starch and evaluation of survival and sensory properties in the cream-filled cake.African Journal Microbiology Research,6, 5511-5517 .http://dx.doi.org/10.5897/AJMR12.1240 ZHOU, Y., MARTINS, E., GROBOILlOT, A., CHAMPAGNE, C.P., NEUFELD (1988). Spectrophotometric quantification of lactic bacteria in alginate and control of cell release with chitosan coating. Journal of Applied Microbiology, 84, 342-348.

ZUIDAM, N. J., SHIMONI, E. (2007). Overview of microencapsulates for use in food products or processes and methods to take them. In: N.J. Zuidam and V. Nedovic (Ed.s).,Encapsulation Technologies for Active Food Ingredients and Food Processing, 83-107, Wiley-Blackwell, New York, NY, USA. http://dx.doi.org/doi:10:1016/j.carbpol.2013.04.068

ZUIDAM, N.J., HEINRICH, (2009). Overview of microencapsulates for use in food products or processes and methods to take them. In: N.J. Zuidam and V. Nedovic (Ed.s)., Encapsulation Technologies for Active Food Ingredients and Food Processing, 83-107, Wiley-Blackwell, New York, NY, USA.https://link.springer.com/chapter/10.1007/978-1-4419-1008-02 